Gynecol. obstet. Invest. 1980;11:I-VI

\title{
Contents, Vol. 11, 1980
}

\section{Contents Vol. 11, 1980}

No. 1

Review

Endocrine Profile and Therapeutic Employment of a New Prolactin-Lowering Drug, Metergoline

Ferrari, C; Reschini, E.iPeracchi, M., and Crosignani, P.G 1

Original Paper

Sex Chromosome and Chromatin Examination in Gynecology

Qinsheng, G.; Liyu, H.;Minyi, T.; Yiwen, Z.;Huoshun, T.; Jinxia, L., and

Xienting, $\mathrm{Z} \quad 17$

Human Placental /3-Endorphin

Fraioli, F. and Genazzani, A.R

Placental Transfer of Hydrochlorothiazide

Beermann, B.; Fåhraeus, L.; Groschinsky-Grind, M., and Lindström, B 45

Effects of Acetylcholine on the Clearance of [3H]-Antipyrine in Bilaterally Perfused

Lobules of Human Term Placenta

Welsch,F 49

Current Investigations

Consumption of IgG Serum Fraction by Placental Tissue as an Indicator for Placental Antibodies in EPH-Gestosis

Schuster, E. and Vosberg, A 56

Estrogen Receptors in Normal and Myomatous Human Uteri

Büchi, K. and Keller, P.J 59

Book Reviews 61

No. 2

Original Paper

Cancer of the Endometrium - a Multiparametric Study

Cauchi, M.N.;Goriup, D.;Riglar, C.;Quinn, M.A., and Richardson, C.R 65

Contents

Relaxin in Non-Pregnant Women during Ovarian Stimulation

Thomas, K.; Loumaye, E., and Ferin, J 75

Electrocardiographic Manifestations in Patients with Uterine Myoma

Nakano, R.;Hata, H.; Sasaki, K., and Hirouchi,Y 81

Failure of a Synthetic, Anti-Inflammatory Compound to Alter the Efficiency of the IUD

Peppier, R.D.;Molony, T., and Bast, J.D 88

Cesarean Section in Premature Delivery

Berg, T. and Lindberg, B.S 95

HPL and Estriol Serum Levels and Placental Perfusion as Indexes of Placental Function in EPH

Gestosis and Placental Insufficiency

Gitsch, E.; Janisch, H., and Spona, J 102 
First-Trimester Serum Prolactin Levels in Normal and Complicated Pregnancies

Riss, P.; Mick, R., and Spona, J 113

Studies on /3-Glucuronidase of the Developing Human Placenta

Kushari, J. and Mukherjea, M119

Book Review 128

No. 3

Review

Immunology and Reproduction. I. Sterility Immunology

Mettler, L 129

Original Paper

Lipid Metabolic Studies in Oophorectomized Women: Effects Induced by Two Different

Estrogens on Serum Lipids and Lipoproteins

Silfverstolpe, G.; Gustafson, A.;Samsioe, G., and Svanborg, A 161

Exogenous DHA-S Half-Life: a Good Index of Intrauterine Growth Retardation

Tanguy, G.; Zorn, J.R.;Sureau, C, and Cedard, L 170

Bacteriology of Amniotic Fluid

Creatsas, G.K.; Lolis, D.E.; Pavlatos, M.P., and Kaskarelis, D.B 174

Current Investigation

Annual Meeting of the American Infectious Disease Society for Obstetrics and Gynecology, 1979

Hoyme, U.B. and Fleiner, R 177

Book Review 191

Contents

No. 4

Review

Cardiac Pre-Ejection Period during Prenatal Life

Evers, J.L.H 193

Original Paper

Humoral Endorphin in Human Body Fluids during Pregnancy

Granat, M.;Sharf, M., and Weissman, B.A 214

Dose-Response Study of Fenoterol on Uterine Activity in Labor at Term

Lippert, T.H.; Peters, F.D., and Kidess, E 219

Evaluation of the Supine Pressor Test

Dhall, K. and Dhall, G.I 225

Effects of Synthetic LH-RH and TRH on Pituitary Function in Anencephalic Infants

Furuhashi, N.; Suzuki, M.; Fukaya, T.; Kono, H.; Tachibana, Y., and Shinkawa, O. 231

Trophoblastic Disease: Analysis of 342 Patients

Nakano, R.; Sasaki, K.;Yamoto, M., and Hata, H 237

Book Reviews 243

No. 5

Original Paper

The Difference between Fetal Transcutaneous p02 and Arterial p02 during Labour

Jensen, A. and Künzel, W 249

Ultrasonographic Study of the Placenta in vitro

Iwamoto, V.M.; Hashimoto, T.; Tsuzaki, T., and Maeda, K 265

Plasma cAMP in Normal and Abnormal Human Pregnancy 
Göser, R.; Jaschonek, K.; Kindler, D.; Keller, E., and Schindler, A.E

Effects of Non-Selective and Selective Beta-Adrenergic Agonists on Spontaneous Contractions and Cyclic AMP Levels in Myometrial Strips from Pregnant Women

Andersson, R.G.G.; Berg, G.; Johansson, S.R.M., and Rydén, G 286

Relationship between Mitochondrial ATPase and Membrane Lipids from Developing Human

Placenta

Chakraborti, A.S.; Biswas, R.; Majumdar, R., and Mukherjea, M 294

Lecithin Content of Amniotic Fluid in Twin Pregnancies with and without Long-Term Tocolytic Therapy

Goeschen, K.; Dudenhausen, J.W.; Kynast, G., and Saling, E 301

Recurrent Endometriosis

Punnonen, R.;Klemi, P., and Nikkanen, V 307

Contents

No. 6

Original Paper

Hyperprolactinemic Primary Amenorrhea: Case Report with Successful Prolactin-Lowering

Treatment and Review of the Literature

Ferrari, C.iTelloli, P.; Rampini, P., and Caldara, R 317

In vitro Studies of the Adherence oîNeisseria gonorrhoeae and Other Urogenital Bacteria to

Vaginal and Uroepithelial Cells, with Special Regard to the Menstrual Cycle

Forslin, L. and Danielsson, D 327

Adherence in vitro of Neissería gonorrhoeae, Escherichia coli and Group B Streptococci to Vaginal Epithelial Cells of Post-Menopausal Women

Forslin, L.; Danielsson, D., and Falk, V 341

Condylomatous Lesions of the Uterine Cervix with Special Reference to Squamous Cell

Carcinogenesis

Syrjänen, K.J 350

Plasma c-AMP during the Normal Menstrual Cycle and under Different Hormonal Treatment

Göser, R.; Kindler, D.; Keller, E., and Schindler, A.E 365

Book Reviews 373

Author Index 376

Subject Index 377 